in Galvanism", printed in London in 1803, has the titlepage embellished with a representation of the medal. Altogether twenty-eight items are included in the bibliography, all of them being very fully described, while there are photographs of several of the title. pages.

\section{Radcliffe Observatory, Pretoria}

THE date of completion of the 74-inch reflector for the new Radeliffe Observatory at Pretoria has been further postponed by a second unsuccessful attempt to cast the disk of Pyrex glass for the large mirror. The first disk was cast by the Corning Glass Company in July 1936, and on being taken from the annealing oven in the following December was found to be useless. A second disk was cast in June of this year, and the disappointing, and unexpected, news has recently been received that this disk also has been a failure. The company is proceeding to make a third disk, and it is to be hoped that on this occasion better fortune will attend its efforts. The other arrangements, though somewhat behind schedule, have been proceeding with greater smooth. ness. The buildings of the Observatory on the magnificent site to the south-east of Pretoria, 600 feet above the city, which was generously presented to the Radcliffe Trustees by the municipality, are nearly completed. They consist of an office block, three residences and the circular building of brick and concrete to house the telescope.

THE Radeliffe-observer (Dr. H. Knox-Shaw) and Mr. E. G. Williams, the second assistant, have already taken up residence at the Observatory, but Dr. R. O. Redman, the chief assistant, is remaining in England for the present to superintend the construction of subsidiary apparatus. The steel revolving turret, under construction by the Cleveland Bridge Com. pany, is due to reach Pretoria early in the new year, to be followed a couple of months later by the mechanical parts of the telescope, which Sir Howard Grubb, Parsons and Co. have nearly finished. It had been planned to have the large mirror for the 74-inch telescope aluminized when completed, in view of the marked success of this form of reflecting surface as applied to the large mirrors in America. There is, however, no apparatus in England capable of dealing with a mirror of this size, and the estimated cost of the outfit, vacuum chamber and pumps, namely, $£ 1,500$, is much more than the resources of the Radcliffe Trustees; already greatly strained by the recent rise in the cost of materials, can afford. It seems likely, therefore, that the new telescope, although thoroughly up to date in other respects, will have, at any rate to begin with, a silvered mirror.

\section{Exhibition of Wilson Track Photographs}

It is now twenty-five years since C. T. R. Wilson first succeoded in making visible and photographing the tracks of single ionizing particles by his condensation method. An exhibition has been arranged at the Science Museum, South Kensington, to illustrate the great variety of effects which have been investigated by means of Wilson chambers during the past twenty-five years. The exhibition will be open free to the public from November 19 until the end of February 1938. The centre-piece of the exhibition is Wilson's original apparatus with which the photographs published in 1912 were taken; the apparatus has been kindly lent by the Cavendish Laboratory, Cambridge, where Wilson's pioneer work was carried out. The remainder of the exhibition consists of a collection of more than eighty photographs, which have been contributed by research workers from many countries. An introductory group of twelve photographs illustrates in as simple a way as possible some of the main properties of alpha and beta rays, X-rays and cosmic rays, for the benefit of those who are not familiar with them. The main collection of photographs is arranged in a series of groups showing typical effects produced by alpha, beta and gamma rays, $\mathrm{X}$-rays, protons, deuterons, neutrons and cosmic rays, while a small group illustrates the phenomenon of induced radioactivity. The section devoted to cosmic rays includes a copy of the photograph taken by Anderson in 1932 which gave him conclusive evidence for the existence of the positive electron, while the discovery of cosmic-ray 'showers' is illustrated by copies of Skobelzyn's pioneer photographs, from which he showed that pairs and groups of 'straight' cosmic ray tracks occur more frequently than is to be expected by chance. In order to bring home to visitors to the exhibition the three-dimen. sional character of Wilson tracks a number of pairs of stereoscopic transparencies have been mounted for viewing in turn in a stereoscope. A small handbook (London : Science Museum, or H.M. Stationery Office, 6d., by post $7 d$.) has been prepared by Dr. F. A. B. Ward, an officer of the Museum, who has arranged the exhibition.

\section{Indian Hydro-electric Development}

THE hydro-electric power scheme, known as the "Ganges Grid", was formally inaugurated on November 2, when Sir Harry Haig, Governor of the United Provinces, opened two new generating stations near Meerut, which are supplied with water-power from the Ganges Canal. The potentialities of the canal as a source of power were first investigated in 1920 in connexion with a series of local applications, and these gradually led to the development of the available resources on a larger scale, in order to extend the benefits of agricultural irrigation over a wide area. The exploitation of the "Grid" project has cost Rs. 343 lakhs (more than $£ 2,500,000$ ) and it now produces a gross output of 29,000 kilowatts. The energy is distributed by means of some four thousand miles of transmission lines to 1,600 substations scattered over the eight western districts of the United Provinces; thence it is supplied to 88 towns for the purpose of pumping water from rivers or from State tube-wells for land irrigation. The power is also utilized to work agricultural machinery on private farms. Sir Harry opened at the same time the State tube-well irrigation system, consisting 
of considerably more than a thousand wells, the greater number of which are in operation and irrigate an area of a million and a half acres. The capital outlay on the system has been about Rs. 126 lakhs $(£ 945,000)$. The execution of the "Grid" project has been in the hands of Sir William Stampe, formerly chief engineer of the Irrigation Department of the United Provinces.

\section{Tring Museum}

About the time of the recent meeting of the British Association in Nottingham, it was announced in the Press that the late Lord Rothschild had bequeathed the buildings and collections of his museum at Tring to the nation on condition that the trustees of the British Museum should undertake their custody and maintenance. The president of the Association, Sir Edward Poulton, expressed in his address the hope that this condition would be accepted, and the committee of Section D (Zoology) forwarded a resolution to the Council, recording its opinion "that the continuance of the Tring Museum as an active centre of scientific research is a matter of the utmost importance from a national, and indeed from an international, point of view. For many years", the resolution continues, "the collections preserved there, more particularly the vast and unequalled collection of Lepidoptera, have attracted research workers from all over the world and have been the means of adding largely to our understanding of the problems of geographical variation. The Sectional Committee earnestly desire that the permanent conservation of these collections and the continuance of the facilities for their study provided by the munificence of the late Lord Rothschild will be ensured by their being placed in the custody of the Trustees of the British Museum." The Council of the Association has now adopted this resolution.

\section{Royal Institute of International Affairs}

THE report of the Council of the Royal Institute of International Affairs submitted to the eighteenth annual general meeting on November 2 refers to the establishment of a chair of international economics at the Institute, Chatham House, London, S.W.1, as a result of a gift of $£ 20,000$ from Sir Henry Price. Prof. Allan G. B. Fisher, of the University of Western Australia, has been appointed as the first holder of this chair and will assume his duties in January 1938. It is hoped that this is the first of what will become a group of research chairs devoted to the study of international affairs, and the council contemplates the establishment of research chairs in British Commonwealth relations, international law and institutions and Far Eastern affairs as soon as provision can be made for them. In addition to these important developments, which were largely inspired by the work of Prof. Arnold Toynbee, holder of the Stevenson research chair in international history, the council has been able to maintain its programme of research by individual scholars and by study groups through the support of the trustees of the Rockefeller
Foundation, who in January 1937 renewed for a further five years their grant of $£ 8,000$ a year. Four reports in the Study Group Series were completed during the year, covering "The British Empire", "The Problem of International Investment", "The Colonial Problem" and "The Republics of South America : a Political, Economic and Cultural Survey". Particulars of these, and of other publications of the Institute, are included in an appendix. The Rockefeller Foundation has also made a special grant for an investigation of the refugee problem. The report includes particulars of a number of other research projects which are in progress as well as meetings held and study groups in being. It is expected that the African Research Survey will be completed and published early in 1938, the preliminary survey having been extended to cover administration, economics, scientific research and social relations.

\section{Tyneside Geographical Society}

THE Tyneside Geographical Society celebrated its fiftieth year of existence at Newcastle-upon-Tyne on November 4-6. On November 4 a jubilee meeting was held with the president of the Society, the Duke of Northumberland, in the chair. The chief speaker at this meeting was Sir William Goodenough, who was one of the two representatives of the Royal Geographical Society at the celebrations. After this meeting, a dinner was held at the Royal Station Hotel, when Lord Polwarth, president of the Royal Scottish Geographical Society, proposed the health of the Tyneside Geographical Society. Sir Thomas Oliver acknowledged the toast and included in his response references to the past activities of the Society over the last fifty years. The health of the guests was proposed by Mr. Herbert Shaw, who held the office of secretary of the Society for nearly forty years. He expressed the gratitude of the Society to the Royal Geographical Society, the Royal Scottish Geographical Society, the Geographical Association and the Manchester Geographical Society for sending representatives to the celebrations. The toast was acknowledged by Lord Eustace Percy, rector of King's College, and by Prof. E. G. R. Taylor of Birkbeck College, University of London. On November 5 the Herbertson Memorial Lecture of the Geographical Association was delivered in King's College by Prof. A. G. Ogilvie, of the University of Edinburgh. The subject of the lecture was "Minerals, Land Forms and Life". On November 6 an exhibition of geographical materials, publications and appliances was held, the official opening ceremony being performed by Lord Eustace Percy.

\section{County Library at Ruislip}

That a timbered barn, reputed to be of medieval age, used in olden days for the storage of corn and later for haybinders' work and general farm products, might be saved by its own appeal through adaptation for the needs of a public county library is a con. sideration which might well enter the minds of educational authorities in those rapidly expanding rural areas where sites are valued at exorbitant rates 